\title{
Rheological and sensorial evaluation of yogurt incorporated with red propolis
}

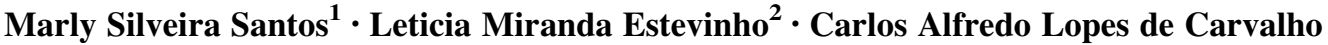 \\ 3 - Antonio Leandro da Silva Conceição ${ }^{3}$ - Rogeria Comastri de Castro Almeida ${ }^{1}$
}

Revised: 6 September 2019/ Accepted: 24 October 2019

(C) Association of Food Scientists \& Technologists (India) 2019

\begin{abstract}
The aim of the present study was to evaluate the use of red propolis extract, as a natural additive, in yogurt. For this, yogurt was produced with red propolis extract (YRP), to replace the additive chemical potassium sorbate, used in the commercial yogurt (CY). Analysis for apparent viscosity, texture and sensorial acceptance were performed. Apparent viscosity and texture measurements of the samples were similar to the control. Sensory evaluation showed that the samples of YRP reached a mean score of 9 on the hedonic scale, the same score found for CY. Regarding the purchase intention, the samples of YRP showed a positive intention by $64.45 \%$ of the consumers, and for CY, $68.89 \%$. For the taste, texture, aroma and consistency, the scores were in the range from 8 to 10 , for both samples. It
\end{abstract}

Rogeria Comastri de Castro Almeida

rogeriac@ufba.br

Marly Silveira Santos

marly.nutr@gmail.com

Leticia Miranda Estevinho

leticia@ipb.pt

Carlos Alfredo Lopes de Carvalho

calfredo.carvalho@gmail.com

Antonio Leandro da Silva Conceição

leandrosilvaufrb@hotmail.com

1 School of Nutrition, Federal University of Bahia, Rua Basílio da Gama, s/n, Canela, Salvador, BA CEP: 40.110-160, Brazil

2 CIMO-Mountain Research Center, Department of Biology and Biotechnology, Agricultural College of Bragança, Polytechnic Institute of Bragançą, Campus Santa Apolónia, CEP: 5300-253, Bragançą, Portugal

3 Center of Agricultural Sciences, Environmental and Biological, Federal University of Bahia Recôncavo, Rua Rui Barbosa, $\mathrm{n}^{\circ} 710$, Centro, Cruz das Almas,

BA CEP: 44.380-000, Brazil can be concluded that the yogurt incorporated with red propolis presents potential for its commercialization in the Brazilian market.

Keywords Red propolis - Sensory characteristics · Yogurt $\cdot$ Potassium sorbate

\section{Introduction}

Yogurt is the product resulting from the fermentation of pasteurized or sterilized milk, incorporated with cultures of Streptococcus salivarius subsp. thermophilus and Lactobacillus delbrueckii subsp. bulgaricus, with or without other lactic acid bacteria added. These bacteria, called probiotics, bring many health benefits like gastrointestinal regulation and stimulation of the immune system (Mathias et al. 2011).

Some additives used as antioxidants and preservatives in foods have proven to be unhealthy for consumers. Although they are permitted by Brazilian legislation and considered safe, studies have shown adverse reactions in consumers, such as hyperactivity in children and metabolic disorders, among others (Ribeiro et al. 2010). In the yogurt production, the traditional formulation uses additives such as thickeners, flavorings, acidulants, preservatives and dyes. In this class of products, dyes and preservatives represent the greatest risk, because when in excess, they can cause allergies and digestive and metabolic dysfunctions (Polônio and Peres 2009).

Chemical additives such as potassium sorbate, sodium benzoate and their mixture are commonly used as preservatives with broad-spectrum activity against yeasts and moulds (Koc et al. 2007). Brazilian red propolis presents antibacterial, antifungal, antioxidant and anti-inflammatory 
effects (Pontes et al. 2018). Regarding the antifungal activity, the effect of red propolis appears to be associated with the damage caused to the fungal membrane, affecting the membrane ergosterol and altering its permeability (Pontes et al. 2018).

In recent years, an increase in consumer concern about the use of synthetic preservatives in foods was notified. Then, the preference for natural products has led to an increase in research for natural antioxidants for use in the food industry (Chen 2014).

Natural compounds in bee products, such as wax, pollen, propolis, royal jelly, apitoxin and honey have been searched for foods or therapeutic use.

Propolis is the generic name for the natural resinous material collected by bees (Apis millifera $\mathrm{L}$.) from various parts of plants, such as branches, flowers, shoots and exudates of trees, and modified in the hive by addition of salivary secretions from bees and wax (Lotti et al. 2010; Thamnopoulos et al. 2018).

Red propolis, classified as the 13th type, is found mainly in the mangrove areas of northeast Brazil, in the states of Sergipe, Alagoas, Bahia, Pernambuco and Paraiba (Pontes et al. 2018). Its intense red coloration is due to the oxidation of the exudates in Dalbergia ecastophyllum (L) collected by bees (Daugsch et al. 2008; Cabral et al. 2009).

Chemical composition of red propolis is different from other types of propolis already reported in literature, presenting flavonoids never before described in other varieties of propolis, such as vestitol and neovestitol, biochamine A, liquiritigenin, formononetine and medicarpine (Pontes et al. 2018). The red propolis from Brazil northeast contain isoflavonoids, pterocarpanes, chalcones, flavones, prenylated benzophenones, terpenes and tannins as mainly constituents (Alencar et al. 2007; Righ et al. 2011). Much of these compounds were not present in the other 12 types of Brazilian propolis (López et al. 2014; Freires et al. 2016). Daugsch et al. (2008) also reported that the Brazilian northeastern red propolis contains other compounds such as: rutin, liquiritigenin, daidzein, pinobanksin, quercetin, luteolin, dalbergin, isoliquiritigenin, formononetin, pinocembrin, pinobanksin-3-acetate. The main volatile compounds are trans-anetol, copaeno, methyl-cis-isoeugenol (Nunes et al. 2009). Mendonça et al. (2015) detected the presence of caffeic acid, ferulic acid, umbelic acid, genistein, naringenin and gutiferon $\mathrm{C}$.

Studies have reported the effectiveness of propolis extracts to reduce free radicals and to act as antimicrobials (Chaillou and Nazareno 2009; Netíková et al. 2013; Vargas-Sánchez et al. 2014). Among these compounds, the flavonoids, phenolic acids and their esters, phenolic aldehydes, alcohols and ketones, quinones, steroids and amino acids stand out. These compounds are an important and promising natural substitute for antimicrobial agents commonly used in the food industry (Chaillou and Nazareno 2009). Despite all the beneficial effects, propolis consumption is hampered due to its bitter taste and strong odor, and its low solubility in water (Jansen-Alves et al. 2019).

Due to propolis properties and growing consumer demand for "green products", and because their main constituents are considered GRAS (Burdock 1998; LuisVillaroya et al. 2015), propolis has gained popularity as a natural preservative for new applications in food and beverage production (Lacerda et al. 2011; Moreira et al. 2008). However, López et al. (2015) alert for its safe user.

The objective of this study was to evaluate the use of the red propolis extract, as a natural additive in yogurt, to replace the chemical additive potassium sorbate used in commercial yogurt.

\section{Materials and methods}

\section{Propolis sample}

The samples used in this study ( $\mathrm{n}=5 ; 300 \mathrm{~g}$ each one) consisted of crude extracts of red propolis produced by Apis mellifera $\mathrm{L}$. bees, collected from Canavieiras city (S $15^{\circ} 40^{\prime} 30^{\prime \prime}$ and $\left.\mathrm{W} 38^{\circ} 56^{\prime} 50^{\prime \prime}\right)(\mathrm{n}=4)$ and Ilhéus city ( $\mathrm{S}$ $14^{\circ} 47^{\prime} 20^{\prime \prime}$ and $\left.\mathrm{W} 39^{\circ} 02^{\prime} 58^{\prime \prime}\right)(\mathrm{n}=1)$, Bahia state, northeast Brazil, and provided by the INSECTA laboratory of the Federal University of Bahia Recôncavo (UFRB).

The red propolis sample was initially macerated and, after that, aliquot of $1 \mathrm{~g}$ was placed in a Falcon-tube with $12.5 \mathrm{~mL}$ of $70 \%$ ethyl alcohol; vortexed (Loccus, 3800) and allowed to stand for about $12 \mathrm{~h}$. The extraction was carried out in an ultrasonic bath (Thorton, 345) for $60 \mathrm{~s}$, followed by centrifugation for $5 \mathrm{~min}$ at $3000 \mathrm{rpm}$ (SP Labor, 154). After $1 \mathrm{~h}$, the sample was filtered in quantitative filter paper (Watman, no. 1) directly into a Petri dish and placed in an exhaust hood (temperature ranged from 19 to $21^{\circ} \mathrm{C}$ ) (Permution, CEO710) for $24 \mathrm{~h}$, until total evaporation of ethyl alcohol. The dried extract obtained was packed in Eppendorf tubes (Park et al. 1998).

\section{Minimal inhibitory concentration and minimal biocide concentration}

Inhibitory effect of red propolis was determined using clinical isolates of bacteria and yeasts belonging to the microorganism collection of Agricultural College of Bragança, Portugal (ESA), and American Type Collection (ATCC): Staphylococcus aureus (ESA 321), Salmonella Enteritidis (ESA 87), Candida albicans (ESA 115), Staphylococcus aureus (ATCC 43300), Salmonella enteritidis (ATCC 13076) and Candida albicans (ATCC 10231). 
The inoculums were prepared in saline solution $(0.85 \%$, $\mathrm{w} / \mathrm{v}$ ) and cell suspensions were standardized using the McFarland scale adjusted to 0.3 for bacteria (absorbance at $540 \mathrm{~nm}$, ca $\sim 10^{8} \mathrm{CFU} / \mathrm{mL}$ ), and 0.5 for yeasts (absorbance at $\left.640 \mathrm{~nm}, \mathrm{ca} \sim 10^{6} \mathrm{CFU} / \mathrm{mL}\right)$. Then, serial dilutions were done (López et al. 2015).

The minimum inhibitory concentration (MIC) was determined by using Brain Heart Infusion broth (BHI) and in Yeast Extract-Peptone-Dextrose broth (YEPD), for bacteria and yeast, respectively. In each well of 96-well polystyrene microplates was placed $100 \mu \mathrm{L}$ of the red propolis solubilized in dimethyl sulfoxide (DMSO $2.5 \%$, $\mathrm{v} / \mathrm{v}$ ) (adapted from Morais et al. 2011) at different concentrations $(25 \mu \mathrm{g} / \mathrm{mL}, 50 \mu \mathrm{g} / \mathrm{mL}, 100 \mu \mathrm{g} / \mathrm{mL}, 500 \mu \mathrm{g} /$ $\mathrm{mL}, 1000 \mu \mathrm{g} / \mathrm{mL}, 2500 \mu \mathrm{g} / \mathrm{mL}, 500 \mu \mathrm{g} / \mathrm{mL}, 10,000 \mu \mathrm{g} /$ $\mathrm{mL}, 12,500 \mu \mathrm{g} / \mathrm{mL}$ and $15,000 \mu \mathrm{g} / \mathrm{mL}$ ) and added $100 \mu \mathrm{L}$ of the suspension of the microorganism test. $100 \mu \mathrm{L}$ of culture medium with $100 \mu \mathrm{L}$ of microorganism test was used as positive control and $200 \mu \mathrm{L}$ of culture medium without microorganism as negative control. Inoculated culture medium with DMSO and amphotericin and gentamicin antibiotics controls were performed too.

The microplates were incubated at $37^{\circ} \mathrm{C}$ for $24 \mathrm{~h}$ for bacteria and $48 \mathrm{~h}$ for yeasts. After that, $20 \mu \mathrm{L}$ of triphenyl tetrazolium chloride (TTC) solution were added in all wells and a new incubation step was carried out for 2 and $3 \mathrm{~h}$ for bacteria and yeasts, respectively (Tsukatani et al. 2008).

MIC were defined as the lowest concentration of inhibitory microorganism with no turbidity of the culture medium. From the wells where there was no change in color, an aliquot of $20 \mu \mathrm{L}$ was removed, inoculated in Petri dishes and incubated at $37{ }^{\circ} \mathrm{C}$ for $24 \mathrm{~h}$ (bacteria) and $48 \mathrm{~h}$ (yeasts). MBC was determined in plaques where growth was less than or equal to $10 \mathrm{CFU}$. The results were expressed as Minimum Inhibitory Concentration (MIC, $\mu \mathrm{g}$ / $\mathrm{mL}$ ) and Minimum Biocide Concentration (MBC, $\mu \mathrm{g} / \mathrm{mL}$ ). The experiments were run in triplicate for each strain.

\section{Preparation of the yogurt}

Commercial yogurt flavored with strawberry, produced with the chemical additive potassium sorbate, was purchased from the retail market in the city of Cruz das Almas, BA, Brazil.

The production of yogurt with red propolis extract and strawberry pulp (YRP), without addition of potassium sorbate, or another additive, and sensorial analysis, were carried out in INSECTA laboratory (Federal University of Bahia Recôncavo, Cruz das Almas, BA, Brazil). The produced yogurt was "stirred yogurt" type (adapted from Robert 2008). For that, $1000 \mathrm{~mL}$ of UHT whole milk and powdered milk $(1 \%, \mathrm{w} / \mathrm{v})$ were boiled and sugar $(12.6 \%$, w/v) was added, following to rapid cooling (ice bath), until reaching $42 \pm 2{ }^{\circ} \mathrm{C}$. Then, commercial lactic culture (Lactobacillus acidophilus, $1 \times 10^{6} \mathrm{UFC} / \mathrm{g} ;$ Bifidobacterium, $1 \times 10^{6} \mathrm{UFC} / \mathrm{g}$ and Streptococcus thermophilus) was added following recommendations of the manufacturer (BioRich $^{\circledR}$, Christian Hansen, Horsholm, Denmark) (400 mg sachet-0.04\%, w/v). The temperature control during the whole process was carried out with a digital thermometer (Mimipa MV-363, São Paulo, SP, Brazil). The product was placed in hermetical glass containers (240 g capacity) (Duran (C) Mainz, Germany) and kept in an incubator (Q317M-32, Quimis, Diadema, SP, Brazil) at $42 \pm 2{ }^{\circ} \mathrm{C}$ for $6 \mathrm{~h}$. Afterwards, the product was transferred to refrigeration $\left(4 \pm 2{ }^{\circ} \mathrm{C}\right)$ for $48 \mathrm{~h}$, and then the curd was broken. Red propolis extract $(0.05 \%$, w/v; $0.046 \%$, w/w) and the pasteurized strawberry pulp $(10 \%, w / v)$ were added, and the product was kept at $4 \pm 2{ }^{\circ} \mathrm{C}$, until the analysis. The concentration of red propolis used in the yogurt production was determined based on the results found in the MIC and MBC tests. The pasteurized strawberry pulp was purchased frozen in the market. The defrosting was made in a refrigerator for 5-6 $\mathrm{h}$, before the addition in the yogurt.

\section{Shelf-life}

To determine the shelf life of the yogurts, storage under refrigeration for at least 28 days was performed (Fernandes et al. 2011). The yogurts were evaluated for microbial stability at $0,7,14,21$ and 28 days, and the results were compared to the current Brazilian standards for fermented milks (Brasil 2001). Counts of psychrotrophic microorganisms (Cousin et al. 2001), lactic acid bacteria (Richter and Vedamuthu 2001), yeasts and moulds (ISO 2008) and coagulase-positive staphylococci (Lancette and Tanini 2001) were evaluated. Total coliforms and Escherichia coli (AOAC 2012), and Salmonella spp. (AOAC 2003) were investigated too.

\section{Apparent viscosity and texture}

The analysis for apparent viscosity and texture were carried out in the laboratory of Pharmacy School from Federal University of Bahia (Salvador, Bahia, Brazil). The apparent viscosity was measured in a concentric cylinder rheometer (Haake Rheotest mod 2.1, Medingen, Germany) coupled with a wash water for temperature control and shear rate of 25-1000/s. The rheological data were adapted to the Ostwald-de-Waele model (Assis et al. 2014):

$\mu=K \gamma^{(n-1)}$,

where $\mu$ is the apparent viscosity; $K$ the consistency index; $\gamma$ the shear rate and $n$ the flow behavior index. The viscosity results were expressed in $\mathrm{mPa}$. 
The texture was determined using the Stable Micro Systems Texturometer (TAX-XT Plus model) with the following parameters: firmness, adhesiveness, gumminess, cohesiveness and elasticity. Samples were evaluated in triplicates in the yogurt recipient (height $=10 \mathrm{~cm}$ ). For the tests, the cylinder probe SMSP/1SP was used, with the parameters: pre-test velocity, $2.0 \mathrm{~mm} / \mathrm{s}$; test speed, $2.0 \mathrm{~mm} / \mathrm{s}$; post-test velocity, $2.0 \mathrm{~mm} / \mathrm{s}$; distance of the penetration tool in the sample, $5 \mathrm{~mm}$; contact time, $5 \mathrm{~s}$; contact force, $5.1 \mathrm{~g}$ (Ramos et al. 2009).

\section{Sensory acceptance and purchase intention}

The sensory acceptance of yogurt with red propolis (YRP) and commercial yogurt (CY) was performed with 90 untrained individuals living in the city of Cruz das Almas, Bahia, northeastern Brazil, using the acceptance test. As a criterion for research participation, the consumers were asked about health problems, such as lactose intolerance and/or allergy to apicultural products. Informed consent, previously approved by the Ethics Committee of the School of Nutrition of the Federal University of Bahia, was provided by each participant (protocol number 2.627.116).

The consumers were instructed for completing the form (Nassu et al. 2010) and encouraged to indicate how much they liked or disliked each sample, using a structured hedonic scale of 10 points, with extremes between "extremely liked" and "extremely disliked", where 0-4 represented "I did not like"; 5, "Indifferent"; and 6-10 "I liked it".

Samples were randomly offered in disposable cups with a capacity of $50 \mathrm{~mL}$, coded with three-digit random numbers, corresponding to the yogurt with red propolis (YRP) and the commercial yogurt (CY). Each participant was allocated in an individual cabinet, and the refrigerated samples $\left(4 \pm 2{ }^{\circ} \mathrm{C}\right)$ were distributed to a group of 5 consumers at a time. In the same tasting sheet, scores were given for the appearance, aroma, consistency and taste attributes.

In order to verify the purchase intention, a tasting sheet with the same coding, containing a structured hedonic scale of 5 points, with extremes between "I would certainly buy", and "I certainly would not buy", was used.

The Acceptability Index (AI) was calculated by the equation described by Castro et al. (2007):

$\% A I=A \times 100 / B$.

where: $A=$ mean score of the product and $B=$ maximum score attributed to product.

\section{Statistical analysis}

For sensory evaluation, $\mathrm{R}$ software (R Core Team 2017) was used and Tukey's test was performed at 1 and 5\% probability.

\section{Results and discussion}

\section{Inhibitory effect of red propolis in yogurt}

Results of the Minimal Inhibitory Concentration (MIC) and Minimal Biocide Concentration (MBC) indicated that all the samples tested showed antimicrobial activity against the microorganism evaluated. For Staphylococcus aureus ATCC 43300 , the MIC ranged from 50 to $500 \mu \mathrm{g} / \mathrm{mL}$ and the MBC between 100 and $500 \mu \mathrm{g} / \mathrm{mL}$. The growth of $S$. aureus ESA 321 (clinical isolate) was inhibited for concentrations ranging from 100 to $500 \mu \mathrm{g} / \mathrm{mL}$, and the MBC, $500-5000 \mu \mathrm{g} / \mathrm{mL}$. The MIC for Salmonella Enteritidis ATCC 13076 ranged from 50 to $500 \mu \mathrm{g} / \mathrm{mL}$ and MBC from 500 to $5000 \mu \mathrm{g} / \mathrm{mL}$. Salmonella Enteritidis ESA 87 showed MIC values ranging from 50 to $500 \mu \mathrm{g} / \mathrm{mL}$ and MBC from 100 to $5000 \mu \mathrm{g} / \mathrm{mL}$. Related to action against Candida albicans ATCC 10231 and Candida albicans ESA 115 , red propolis showed the same fungistatic activity $(\mathrm{MIC}=500 \mu \mathrm{g} / \mathrm{mL})$ and fungicide activity $(\mathrm{MBC}=500$ $\mu \mathrm{g} / \mathrm{mL})$.

\section{Shelf-life}

The antimicrobial activity of propolis is mainly attributed to the presence of flavonoids, acids, esters, phenolic aldehydes and ketones present in the resin (Luis-Villaroya et al., 2015). The mechanism is considered complex and can be attributed to the synergism between flavonoids, hydroxyls and sesquiterpenes (Gonsales et al. 2006).

In this study, the antimicrobial activity in the YRP samples was measured in the products under refrigeration $\left(4{ }^{\circ} \mathrm{C} \pm 2{ }^{\circ} \mathrm{C}\right.$ ) at 0 (zero) $7,14,21$ and 28 days. During the entire storage time, all samples showed the absence of Salmonella spp., total coliforms and Escherichia coli. Psychrotrophic microorganisms, yeasts and moulds and coagulase-positive staphylococci showed counts $<10$ $\mathrm{CFU} / \mathrm{mL}(<1.0 \log \mathrm{CFU} / \mathrm{mL})$. These results demonstrated that all the samples were within the Brazilian standards for fermented milks (absence of Salmonella spp. in $25 \mathrm{~mL}$; coliforms at $45{ }^{\circ} \mathrm{C}$, maximum of $10 \mathrm{MPN} / \mathrm{mL}$; yeasts and moulds, maximum of $2 \times 10^{2} \mathrm{CFU} / \mathrm{mL}$; and lactic acid bacteria, minimum of $10^{7} \mathrm{CFU} / \mathrm{mL}$ ) (Brasil 2001). 


\section{Apparent viscosity and texture}

The consistency and viscosity of yogurt are one of the main attributes that influence the quality and acceptance. Figure 1 shows the yogurt fluidity produced with the red propolis extract and strawberry pulp (YRP), without addition of potassium sorbate.

The results showed a non-Newtonian and pseudoplastic fluid behavior, with a mean apparent viscosity of $307.27 \mathrm{mPa}$ (Fig. 1). It was verified that the reduction in the viscosity was proportional to the increase of the shear rate applied, thus, with increasing speed the food became more liquid and fluid.

Many factors can affect the rheological properties of yogurt, such as solids, proteins and fat contents, temperatures and fermentation used in the production, etc. (Mathias et al. 2011).

Rheological studies, in generally, involve relationships between shear rate and shear stress. In the linear relationship, the fluid is considered Newtonian and its viscosity is constant. However, in many situations, the relationship is not linear, so the fluid is considered non-Newtonian, such as pseudo-plastic fluids that present lower viscosity with the increase of the applied shear rate (Mathias et al. 2011).

Mathias et al. (2011) evaluating rheological behavior of different commercial yogurts, found a smaller value $(236.3 \mathrm{mPa})$ than that verified in the present study. According to Lucey (2002), this behavior can occur due to the weakening of the interactions among the molecules of the product and the decrease in the interaction energy among them. Work performed by Gomes and Penna (2009) confirmed that the yogurt presents a characteristic of a pseudoplastic fluid.

The cohesiveness is defined as the matter property in resisting deformations (Alimoradi et al. 2013). This parameter is also defined by Cruz et al. (2013) as the form/ quantity of product that remains cohesive during its compression. The results of the measures of cohesiveness in

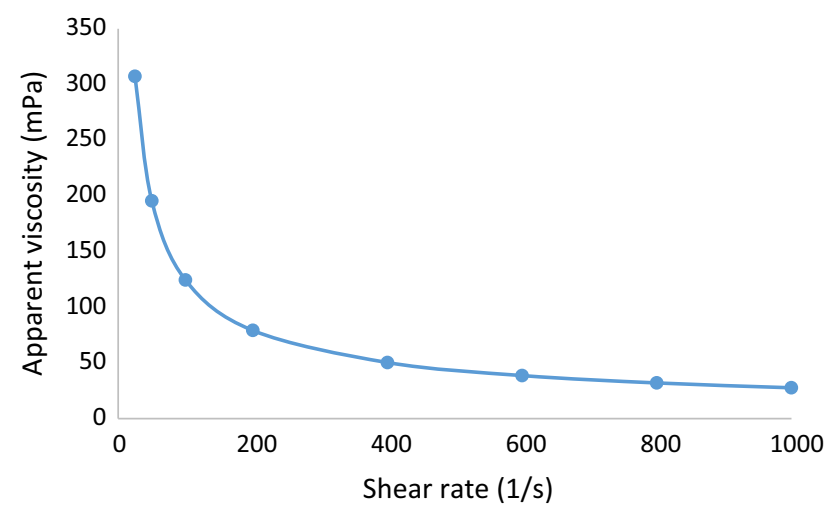

Fig. 1 Apparent viscosity measurements $(\mathrm{mPa})$ in yogurt produced with red propolis this study demonstrated similar behavior among the YRP and control (Fig. 2). In general, the increased cohesiveness is correlated to a higher protein content in the sample.

\section{Sensory acceptance and purchase intention}

Of the total participants in this study, $34.44 \%$ were female and $65.56 \%$ were male. They were predominantly consumers in the age from 20 to $40(45.56 \%)$ years old, with a level of education between incomplete undergraduate, $39.0 \%$, complete undergraduate, $55.44 \%$ and graduate $(5.56 \%)$. Profile identification of the yogurt consumers living in Belo Horizonte, MG, Brazil, was similar to the results of the present work, indicating the predominance of individuals with ages between 20 and $40(55.6 \%)$, with complete or incomplete undergraduate degree $(93.33 \%)$ (Ribeiro et al. 2010). Furthermore, Ferreira et al. (2015) also related that $99 \%$ of the consumers yogurt had incomplete undergraduate degree.

The results of the sensory evaluation showed that both yogurts, with red propolis (YRP) and commercial (CY), presented a high frequency for scores 8,9 and 10, demonstrating that yoghurt with propolis was well accepted by the consumers.

In general, propolis has a very characteristic and strong odor and its addition in food formulations can result in color change and, especially, unpleasant odor to the food (Jansen-Alves et al. 2019). However, in the present study, these undesirable sensorial characteristics were not verified in the samples.

A study performed by Kročko et al. (2014) using the propolis extract associated with ascorbic acid in the sliced baked ham demonstrated that the use of propolis did not interfere in the product acceptance.

Bernardi et al. (2013) evaluated the acceptance of salami with propolis with 50 habitual consumers of salami. Some of the consumers identified the propolis odour in the samples, although they did not know about the addition of the additive in the product. However, the product was generally accepted with responses varying from "liked" to commercial salami (mean of 7.1) and "moderately liked" for salami with propolis (mean of 6.7).

Considering that the all attributes presented scores higher than 7 points in hedonic scale, equivalent to the terms "I liked moderately" to "I liked very much", in high frequencies (Table 1), the YRP was considered as "accepted" (Castro et al. 2007). In the evaluation of appearance, flavor, aroma and texture attributes for both yogurts, it was verified that there were not significant differences $(p>0.05)$ among the samples (Fig. 3).

In the literature there were no data about sensorial acceptance of yogurt produced with propolis, but other foods have been searched. For example, the study of 
Fig. 2 Texture measurements of yogurt with red propolis (YRP) and commercial yogurt (CY)

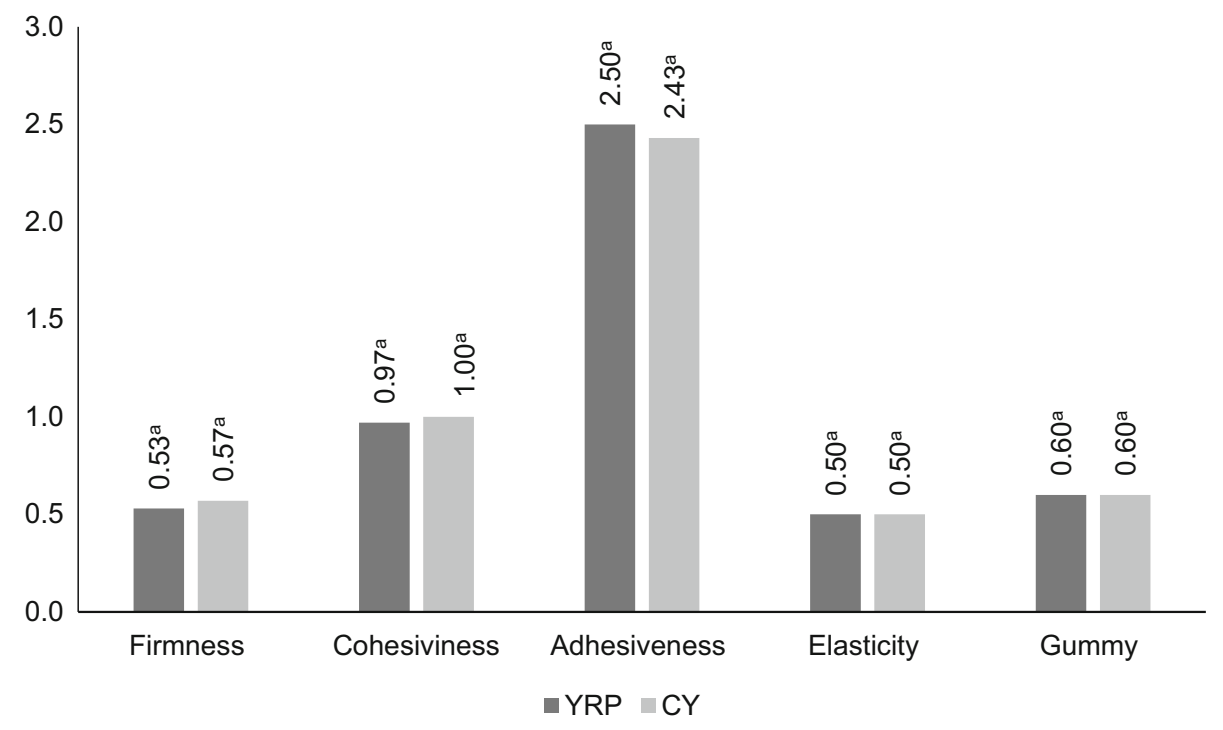

Table 1 Acceptability index for the yogurt samples, according to the evaluated attributes

\begin{tabular}{lll}
\hline Attribute & \multicolumn{2}{l}{ Attribute acceptance index } \\
\cline { 2 - 3 } & Commercial yogurt & Yogurt with red propolis \\
\hline Appearance & $86.56 \pm 1.36$ & $80.28 \pm 1.47$ \\
Aroma & $87.50 \pm 1.29$ & $76.50 \pm 1.70$ \\
Texture & $85.94 \pm 1.86$ & $85.56 \pm 1.32$ \\
Taste & $89.33 \pm 1.22$ & $82.06 \pm 1.47$ \\
\hline
\end{tabular}

Gutiérrez-Cortés and Mahecha (2014) that evaluated the acceptance of sausage with propolis and demonstrated that the product achieved grades higher than 4.0 in the hedonic scale of 9 points for aroma, texture and flavor attributes.

Table 2 shows the dispersion of the values found in both yogurts, the correlation coefficient $(r)$ between each pair of variables, and the correlation among the samples. All correlations $(r)$ followed with asterisks were significant at 1 and 5\% probability by the Tukey' test. The data demonstrated a high correlation between appearance and aroma $(r=0.62)$ and small correlation between texture and aroma

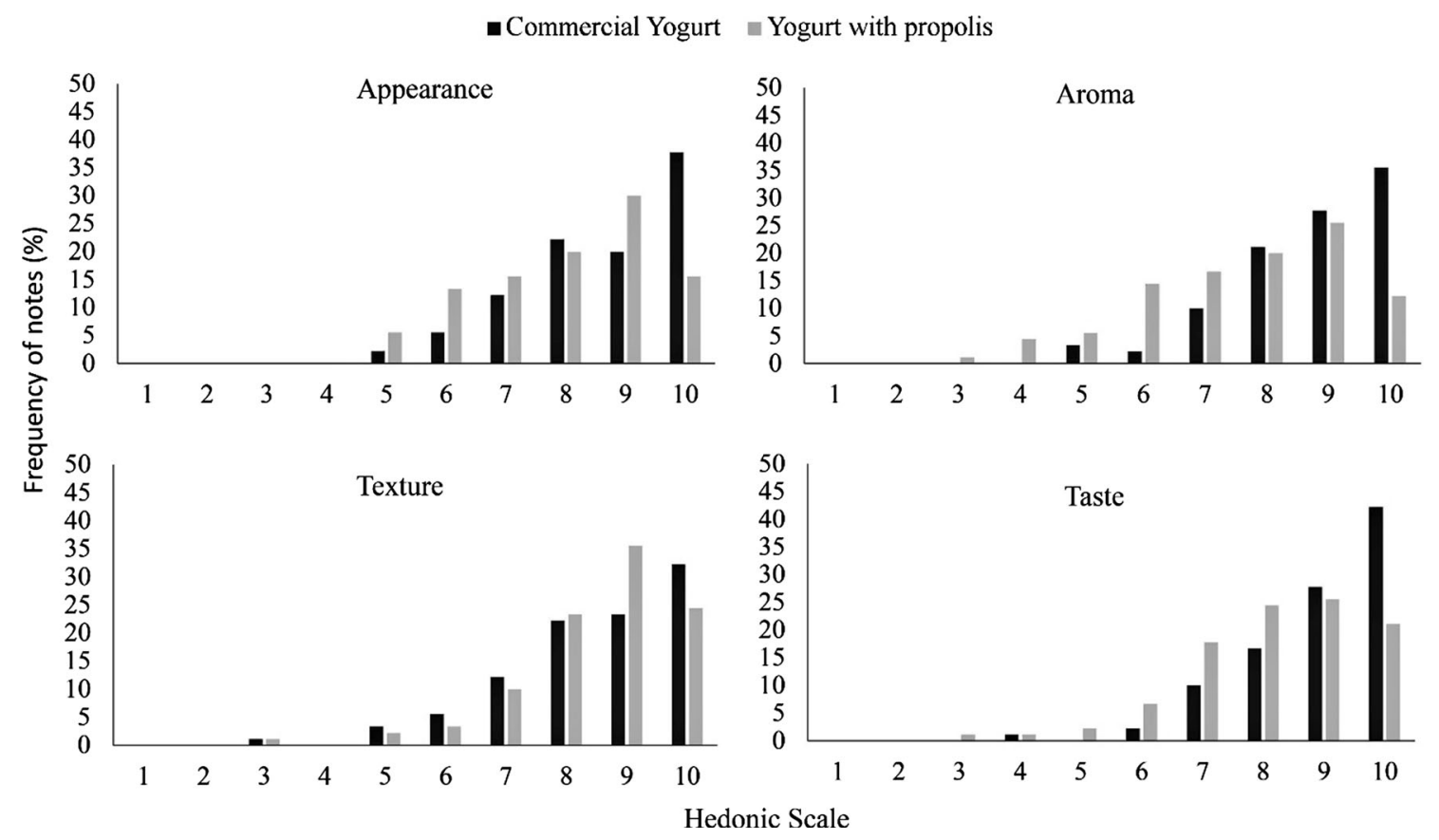

Fig. 3 Sensory acceptance of yogurt with red propolis and commercial yogurt 
Table 2 Correlation coefficient among sensorial attributes in the samples of yogurt with red propolis (YRP) and commercial yogurt (CY)

\begin{tabular}{|c|c|c|c|c|}
\hline Attributes & Appearance & Aroma & Texture & Taste \\
\hline Appearance & 1 & $\begin{array}{l}r(\mathrm{YRP}+\mathrm{CY})=0.62 * * \\
r(\mathrm{YRP})=0.59 * * \\
r(\mathrm{CY})=0.60 * *\end{array}$ & $\begin{array}{l}r(\mathrm{YRP}+\mathrm{CY})=0.34^{*} \\
r(\mathrm{YRP})=0.43^{*} \\
r(\mathrm{CY})=0.29 *\end{array}$ & $\begin{array}{l}r(\mathrm{YRP}+\mathrm{CY})=0.59 * * \\
r(\mathrm{YRP})=0.46^{* *} \\
r(\mathrm{CY})=0.70^{* *}\end{array}$ \\
\hline Aroma & & 1 & $\begin{array}{l}r(\mathrm{YRP}+\mathrm{CY})=0.27 * * \\
r(\mathrm{YRP})=0.31^{* *} \\
r(\mathrm{CY})=0.29 * *\end{array}$ & $\begin{array}{l}r(\mathrm{YRP}+\mathrm{CY})=0.53 * * \\
r(\mathrm{YRP})=0.42^{* *} \\
r(\mathrm{CY})=0.60 * *\end{array}$ \\
\hline Texture & & & 1 & $\begin{array}{l}r(\mathrm{YRP}+\mathrm{CY})=0.35^{* *} \\
r(\mathrm{YRP})=0.35^{* *} \\
r(\mathrm{CY})=0.38^{* *}\end{array}$ \\
\hline Taste & & & & 1 \\
\hline
\end{tabular}

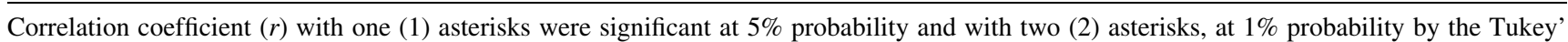
test

$(r=0.27)$, regardless of the sample. The aroma is a characteristic highly related to the taste and this correlation can be observed in highly significant correlation values ( $r=0.42,0.53$ and 0.60 ) presented between these two attributes in the samples evaluated. According to Anzaldúa-Morales (1994), the aroma is an essential property to compose the flavor food. In general, the texture presented a smaller correlation.

In Fig. 4, the first two components (CP1 and $\mathrm{CP} 2)$ explain about $79.1 \%$ of the data variation. Also, can be verified that the aroma, appearance and taste have positive factorial loads in the component 1 (commercial yogurt) and demonstrated a higher influence on the separation of the control samples. Therefore, this component represents a higher relationship among the three sensory attributes. In contrast, the samples of yogurt with red propolis were more influenced by the texture, presenting a negative factorial load in the component 2. As a result, a low relation between the texture and the other attributes was observed. This result can be attributed to a preexisting memory of
Fig. 4 Correlation between texture and other sensory attributes of yogurt with red propolis and commercial yogurt

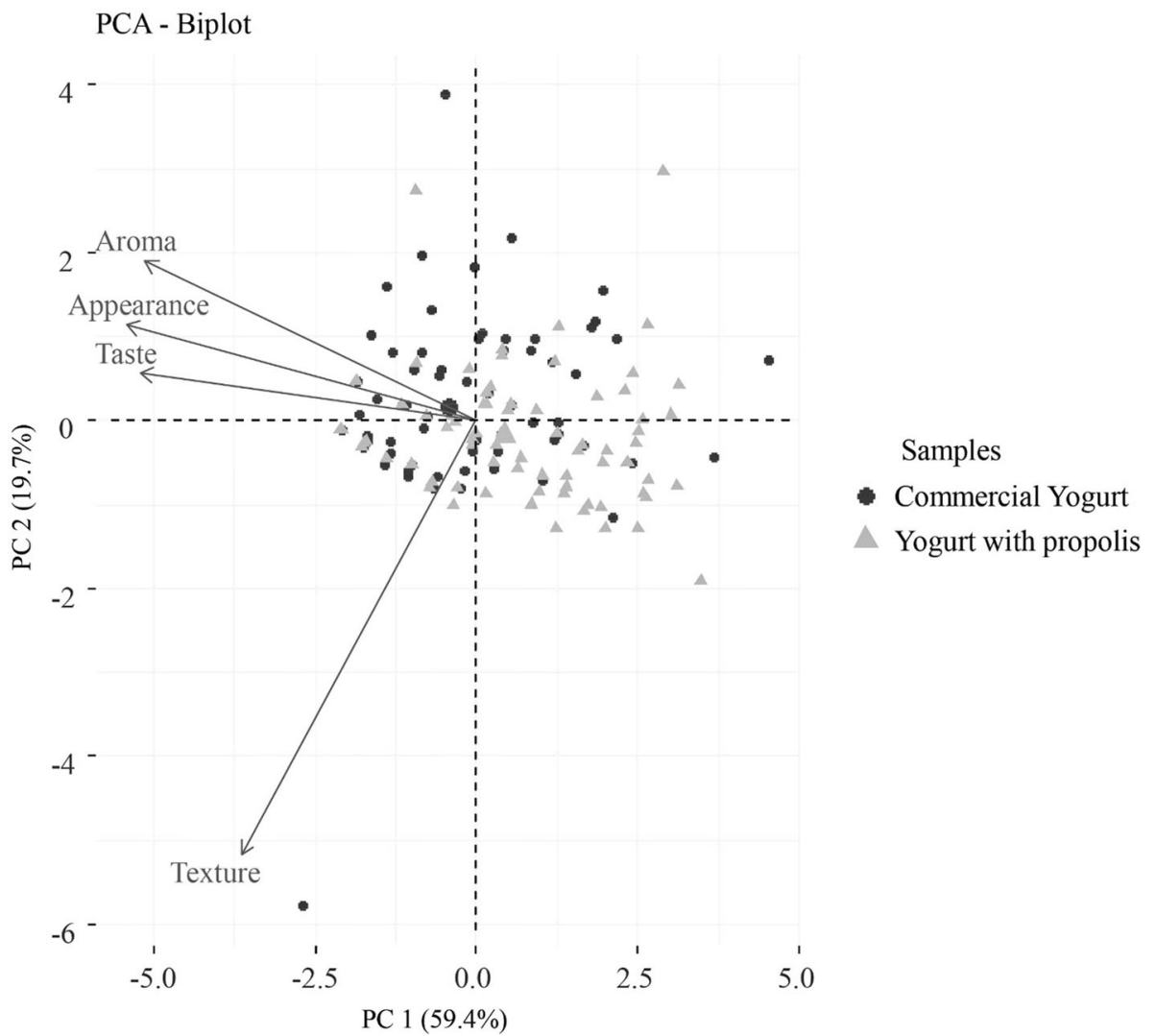


consumers to commercial yogurt, considering that this kind of yogurt is more liquefied and have a texture known by the tasters (Galdino et al. 2010).

Regarding the results of the evaluation of the intention to buy, $96.67 \%$ of the consumers showed interest in buying the commercial product, and $64.45 \%$ showed interest in buying yogurt with addition of red propolis, according to responses: "I would definitely buy" and "I would probably buy".

It is important to mention that the preference of consumers for commercial yogurt was expected, considering that the product had other ingredients in its formulation, such as corn syrup, flavorings, among others, that contributed to flavor and aroma.

\section{Conclusion}

The results of this study demonstrate that the yogurt with red propolis shows apparent viscosity and texture measurements similar to the control, and like other yogurts presented a characteristic of a non-Newtonian pseudoplastic fluid. The product was well accepted and evaluated by most consumers as a product with good purchase intention. According to the acceptability index, the yoghurt produced with the red propolis presented a good potential of consumption and commercialization. From the characteristics presented by the product and those inherent to propolis, such as the presence of bioactive compounds, antimicrobial and antioxidant activities, the yogurt proposed in this work can be classified as a product that is attractive to the public in general, and to the people who seek healthier foods, without the addition of chemical preservatives.

Acknowledgements The authors thank the Coordenação de Aperfeiçoamento de Pessoal de Nível Superior (CAPES), Brazilian government (Finance Code 001), and Leonardo Fonseca Maciel and Denilson de Jesus Assis of the Pharmacy Faculty of Federal University of Bahia, and the technical team of the INSECTA laboratory from Federal University of Bahia Recôncavo for their support during the research.

Funding This research did not receive any specific grant from funding agencies in the public, commercial, or not-for-profit sectors.

\section{Compliance with ethical standards}

Conflict of interest All authors declare no conflict of interest, including financial support or other relationships with other people or organizations, within 3 years from the beginning of this submission, which may inappropriately influence or have any influence on this work.

\section{References}

Alencar SM, Oldoni TL, Castro ML, Cabral IS, Costa-Neto CM, Cury JA, Rosalen PL, Ikegaki M (2007) Chemical composition and biological activity of a new type of Brazilian propolis: red propolis. J Ethnopharmacol 113:278-283. https://doi.org/10. 1016/j.jep.2007.06.005

Alimoradi AH, Yasini SAA, Mozaffari-Khosravi H, Daneshi M, Shirzadi A (2013) Using sesame oil as fat substitute in yogurt. World Sci J 4:208-216

Anzaldúa-Morales A (1994) La evaluación sensorial de los alimentos en la teoría y la prática. Acribia SA, Zaragoza

Assis DS, Brandão LV, de Sousa Costa LA, Figueiredo TV, Sousa LS, Padilha FF, Druzian JIA (2014) Study of the effects of aeration and agitation on the properties and production of xanthan gum from crude glycerin derived from biodiesel using the response surface methodology. Appl Biochem Biotechnol 172:2769-2785. https://doi.org/10.1007/s12010-014-0723-7

Association of Official Analytical Chemistry (AOAC) (2003) Rapid tests kits. http://www.aoac.org/tests/kits/microbiologykits. htm\#salmonella. Accessed 13 April 2018

Association of Official Analytical Chemistry (AOAC) (2012) Official methods of analysis, 19th edn. Maryland AOAC, Gaithersburg, pp $1-3000$

Bernardi S, Josefina CC, Trindade MA, Akemi AC (2013) Italian-type salami with propolis as antioxidant. Ital J Food Sci 25:1-8

Brasil (2001) Agência Nacional de Vigilância Sanitária (ANVISA). Resolução de Diretoria Colegiada (RDC) $n^{\circ} 12,02$ de janeiro de 2001. Regulamento Técnico para Padrões microbiológicos para alimentos, Brasília

Burdock GA (1998) Review of the biological properties and toxicity of bee propolis (propolis). Food Chem Toxicol 36:347-363

Cabral ISR, Oldoni TCL, Prado A, Bezerra RMN, Alencar SA, Ikegaki M, Rosalen PLC (2009) Composição fenólica, atividade antibacteriana e antioxidante da própolis vermelha brasileira. Quim Nova 32:1523-1527. https://doi.org/10.1590/S010040422009000600031

Castro IA, Vila-Real CM, Pires CIS, Pires VC, Pinto NAD, Miranda SL, Rosa CB, Dias AP (2007) Quinoa (Chenopodium quinoa Willd): digestibilidade in vitro, desenvolvimento e análise sensorial de preparações destinadas a pacientes celíacos. Alim Nutr 8:413-419

Chaillou LL, Nazareno MA (2009) Bioactivity of propolis from Santiago del Estero, Argentina, related to their chemical composition. LWT-Food Sci Technol 42:1422-1427. https:// doi.org/10.1016/j.lwt.2009.03.002

Chen J (2014) Food oral processing: some important underpinning principles of eating and sensory perception. Food Struct 9:91-105. https://doi.org/10.1016/j.foostr.2014.03.001

Cousin MA, Jay JM, Vasavada PC (2001) Psychrotrophic microorganisms. In: Downes FP, Ito K (eds) Compendium of methods for the microbiological examination of foods, 4th edn. American Public Health Association, Washington, DC, pp 159-166

Cruz AG, Cavalcanti MR, Guerreiro LMR, Sant'Ana AS, Nogueira LC, Oliveira CAF, Deliza R, Cunha RL, Faria JAF, Bolini HAM (2013) Developing a prebiotic yogurt: rheological, physicchemical and microbiological aspects and adequacy of survival analysis methodology. J Food Eng 114:323-330. https://doi.org/ 10.1016/jfoodeng.2012.08.018

Daugsch A, Moraes CS, Fort P, Park KY (2008) Brazilian red propolis-chemical composition and botanical origin. Evid Based Complement Alternat Med 5:347-363. https://doi.org/10.1093/ ecam/nem057 
Fernandes SS, Coelho RS, Franco RM, Barbosa CG, Luchese RH (2011) Monitoramento da microbiota de iogurtes comerciais. Rev Inst Latic Cândido Tostes 66(382):5-11

Ferreira FCP, Paiva YF, Almeida RBCB, Silva ARM, Araújo AS (2015) Elaboração e avaliação sensorial de iogurte natural com polpa de abacaxi base mel. Caderno Verde de Agroecologia e Desenvolvimento Sustentável 4:99-112

Freires IA, Alencar SM, Rosalen PL (2016) A pharmacological perspective on the use of Brazilian Red Propolis and its isolated compounds against human diseases. Eur J Med Chem 110:267-279. https://doi.org/10.1016/j.ejmech.2016.01.033

Galdino PO, Galdino PO, Fernandes TKS, Oliveira MRT, Rocha APP (2010) Caracterização sensorial de iogurte enriquecido com polpa da palma forrageira (Napoleaco chenillifera). Rev Verde 5:40-53

Gomes RG, Penna ALB (2009) Características reológicas e sensoriais de bebidas lácteas funcionais. Semina 30:629-646

Gonsales GZ, Orsi RO, Fernandes Júnior A, Rodrigues P, Funari SRC (2006) Antibacterial activity of propolis collected in different regions of Brazil. J Venom Anim Toxins Incl Trop Dis $12: 276-284$

Gutiérrez-Cortés C, Mahecha HS (2014) Antimicrobial activity of propolis and its effect on the physicochemical and sensorial characteristics in sausages. Revista Vitae de la Facultad de Química Farmacéutica 21:90-96

International Standards Organization (ISO) (2008) ISO 21527-2. Microbiology of food and animal feeding stuffs. Horizontal method for the enumeration of yeasts and moulds-Part 2: colony count technique in products with water activity less than or equal to 0.95 , Winterthur

Jansen-Alves C, Krumreich FD, Zandoná GP, Gularte MA, Borges CD, Zambiazi RC (2019) Production of propolis extract microparticles with concentrated pea protein for application in food. Food Bioprocess Technol. https://doi.org/10.1007/s11947019-2246-2

Koc AN, Silici S, Mutlu-Sariguzel F, Sagdic O (2007) Antifungal activity of propolis in four different fruit juices. Food Technol Biotechnol 45(1):57-61

Kročko M, Bobko M, Buchko O, Canigová M, Duchová V (2014) Sensory quality, colour and oxidative stability of cured cooked ham with propolis extract. Potravinarstvo Slovak J Food Sci 8(1):102-106. https://doi.org/10.5219/365

Lacerda RCS, Tiveron AP, Alencar SM (2011) Própolis e Segurança Alimentar. Segurança Alimentar e Nutricional, Campinas 18(2):99-106

Lancette GA, Tanini SR (2001) Staphylococcus aureus and staphylococcal enterotoxins. In: Downes FP, Ito K (eds) Compendium of methods for the microbiological examination of foods, 4th edn. American Public Health Association, Washington, DC, pp 387-403

López BG, Schmidt EM, Eberlin MN, Sawaya AC (2014) Phytochemical markers of different types of red propolis. Food Chem 14:174-180. https://doi.org/10.1016/.foodchem.2013.09.063

López BGC, Lourenço CC, Alves DA, Machado D, Lancellotti M, Sawaya ACHF (2015) Antimicrobial and cytotoxic activity of red propolis: an alert for its safe use. J Appl Microbiol 119(3):677-687

Lotti C, Campo FM, Piccinelli AL, Cuesta-Rubio O, MárquezHernández I, Rastrelli L (2010) Chemical constituents of red Mexican propolis. J Agric Food Chem 58:2209-2213. https:// doi.org/10.1021/jf100070w

Lucey JA (2002) Formation and physical properties of milk protein gels. J Dairy Sci 85:281-294. https://doi.org/10.3168/jds.S00220302(02)74078-2

Luis-Villaroya A, Espina L, García-Gonzalo D, Bayarri S, Pérez C, Pagán R (2015) Bioactive properties of a propolis-based dietary supplement and its use in combination with mild heat for apple juice preservation. Int J Food Microbiol 20:90-97. https://doi. org/10.1016/j.ijfoodmicro.2015.03.020

Mathias TRS, Carvalho Junior IC, Carvalho CWP, Sérvulo EFC (2011) Rheological characterization of coffee-flavored yogurt with different types of thickener. Alim Nutr 22:521-529

Mendonça ICG, Porto ICCM, Nascimento TG, Souza NS, Oliveira JMS, Arruda RES, Mousinho KC, Santos AF, Basílio-Júnior ID, Parolia A, Barreto FS (2015) Brazilian red propolis: phytochemical screening, antioxidant activity and effect against cancer cells. Evid Based Complement Alternat Med 15:357

Morais M, Moreira L, Feas X, Estevinho LM (2011) Honeybeecollected pollen from five Portuguese natural parks: palynological origin, phenolic content, antioxidant properties and antimicrobial activity. Food Chem Toxicol 49(5):1096-1101

Moreira L, Dias LG, Pereira JA, Estevinho LM (2008) Antioxidant properties, total phenols and pollen analysis of propolis samples from Portugal. Food Chem Toxicol 46:3482-3485. https://doi. org/10.1016/j.fct.2008.08.025

Nassu RT, Borba H, Verruma-Bernardi MR (2010) Validação de protocolo sensorial para avaliação de carne bovina. Braz J Food Technol 6:152-160

Netíková L, Bogush P, Henrberg P (2013) Czech ethanol-free propolis extract displays inhibitory activity against a broad spectrum of bacterial and fungal pathogens. J Food Sci 78:421-429. https://doi.org/10.1111/1750-3841.12230

Nunes LC, Galindo AB, Deus ASO, Rufino DA, Randau KP, Xavier HS, Citó AMGL, Rolim Neto PJ (2009) Seasonal variability of the constituents of propolis and bioactivity in saline Artermia. Braz J Pharmacogn 19:524-529

Park YK, Ikegari M, Abreu JAS, Alcici NMF (1998) Estudo da preparação dos extratos de própolis e suas aplicações. Ciênc Tecnol Alim 3:313-318

Polônio ML, Peres F (2009) Consumo de aditivos alimentares e efeitos à saúde: desafios para a saúde pública brasileira. Cad Saúde Pública 25(8):656-1657. https://doi.org/10.1590/S0102311X2009000800002

Pontes MLC, Vasconcelos IRA, Diniza MFFM, Pessôa HLF (2018) Chemical characterization and pharmacological action of Brazilian red propolis. Acta Bras 1(1):34-39. https://doi.org/10.22571/ 202526-433868

Ramos TM, Gajo AA, Pinto SM, Abreu LR, Pinheiro AC (2009) Perfil de Textura de Labneh (Iogurte grego). Rev Inst Latic Cândido Tostes 64:8-12

$\mathrm{R}$ Core Team (2017) Language and environment for statistical computing. R Foundation for Statistical Computing, Vienna

Ribeiro VMM, Minim P, Minim RLA, Arruda AC, Ceresino EB, Carneiro HCF, Cipriano PA (2010) Estudo de mercado de iogurte da cidade de Belo Horizonte/MG. Rev Ceres 57:151-156. $737 X 2010000200003$

Richter RL, Vedamuthu ER (2001) Milk and milk products. In: Downes FP, Ito $\mathrm{K}$ (eds) Compendium of methods for the microbiological examination of foods, 4th edn. American Public Health Association, Washington, DC, pp 483-493

Righ AA, Alves TR, Negri G, Marques LM, Breyer H, Salatino A (2011) Brazilian red propolis: unreported substances, antioxidant and antimicrobial activities. J Sci Food Agric 91(13):2363-2370

Robert NF (2008) Dossiê Fabricação de iogurte. SBRT. Rede de Tecnologia do Rio de Janeiro, REDETEC. www.sbrt.ibict.br/ dossie-tecnico/downloadsDT/MzIw

Thamnopoulos I-AI, Michailidis GF, Fletouris DJ, Badeka A, Kontominas MG, Angelidis AS (2018) Inhibitory activity of propolis against Listeria monocytogenes in milk stored under refrigeration. Food Microbiol 73:168-176. https://doi.org/10. 1016/j.fm.2018.01.021 
Tsukatani T, Suenaga H, Higuchi T, Akao T, Ishiyama M, Ezoe K, Matsumoto K (2008) Colorimetric cell proliferation assay for microorganisms in microtiter plate using water-soluble tetrazolium salts. J Microbiol Methods 75:109-116

Vargas-Sánchez RD, Torrescano-Urrutia GR, Acedo-Félix E, Carvajal-Millán E, González-Córdova FA, Vallejo-Galland B, TorresLlanez M (2014) Antioxidant and antimicrobial activity of commercial propolis extract in beef patties. J Food Sci 79:1499-1504. https://doi.org/10.1111/1750-3841.12533

Publisher's Note Springer Nature remains neutral with regard to jurisdictional claims in published maps and institutional affiliations. 